\title{
Dimensions of satisfaction of older adult brazilian outpatients with physical therapy
}

\author{
Dimensões da satisfação do paciente idoso brasileiro com a fisioterapia \\ ambulatorial
}

Diógenes TPM', Mendonça KMPP², Guerra RO²,3

\begin{abstract}
Objectives: To investigate the main dimensions with respect to the satisfaction of geriatric patients undergoing outpatient physical therapy and assess the internal consistency of the measures obtained in the assessment instrument. Methods: An assessment instrument measuring patient satisfaction with physical therapy was used. The instrument contains a 23-item patient satisfaction scale and was developed and validated for the Brazilian population by Mendonça and Guerra (2007)*. The data were collected in the waiting room of 29 private physical therapy clinics in Natal, the capital of the state of Rio Grande do Norte, Brazil. The non-probability sample consisted of 221 cognitively healthy patients aged 60 years and older, who possessed health insurance and who had undergone between 5 and 60 physical therapy sessions at the participating clinics. Results: Four factors with an autovalue greater than 1 were retained in the factorial analysis: patient-therapist interaction; access and assistance by the receptionist and support personnel; physical environment and overall satisfaction; and convenience. The items related to patient-therapist interaction showed the highest reliability and highest complete satisfaction scores, especially the respect and courtesy of the physical therapist (85.5\%). The reliability of the measures obtained with the instrument, using Cronbach's alpha coefficient and directed toward the geriatric population, was $\alpha=0.943$. Conclusions: Physical therapists must give support to these patients, not only through their technical skills, but also by emphasizing an attentive and favorable interpersonal relationship, which were the most reported aspects of older adult patient satisfaction with health care.
\end{abstract}

Keywords: patient satisfaction; physical therapy; quality of health care; age.

*Mendonça KMPP, Guerra RO. Desenvolvimento e validação de um instrumento de medida da satisfação do paciente com a fisioterapia. Rev Bras Fisioter. 2007;11(5):369-76.

\section{Resumo}

Objetivos: Investigar as principais dimensões relacionadas com a satisfação do paciente geriátrico com o tratamento fisioterapêutico ambulatorial e avaliar a consistência interna das medidas obtidas no instrumento de avaliação. Métodos: Foi utilizado o instrumento de avaliação da satisfação do paciente com a fisioterapia, desenvolvido e validado para a população brasileira por Mendonça e Guerra (2007)*, com escala de avaliação da satisfação de 23 itens. Os dados foram coletados na sala de espera de 29 clínicas de Fisioterapia da rede privada de Natal, capital do RN/Brasil. A amostra do estudo foi selecionada de forma não-probabilística e constou de 221 pacientes com idade igual ou superior a 60 anos, com realização de 5 a 60 sessões de fisioterapia naqueles estabelecimentos, sendo usuários de plano de saúde e com condições cognitivas preservadas. Resultados: Quatro fatores com autovalor maior que 1 foram retidos na análise fatorial: interação paciente-terapeuta; acesso e atendimento de recepcionista e pessoal de apoio; ambiente físico e satisfação global e conveniência. Os itens relacionados com a interação paciente-terapeuta apresentaram as mais altas confiabilidades, assim como mais elevados escores de satisfação completa, especialmente o respeito e a gentileza do fisioterapeuta (85,5\%). A confiabilidade calculada para as medidas obtidas com o instrumento, por meio do Coeficiente Alfa de Cronbach e direcionado a população geriátrica, estabeleceu $\alpha=0,943$. Conclusões: $O$ fisioterapeuta deve dar suporte a esses pacientes não apenas com sua qualidade técnica, mas também enfatizando o apoio afetivo e um favorável relacionamento interpessoal, os quais foram aspectos mais representativos da satisfação do paciente idoso com o cuidado de sua saúde.

Palavras-chave: satisfação do paciente; fisioterapia; qualidade dos cuidados de saúde; idoso.

*Mendonça KMPP, Guerra RO. Desenvolvimento e validação de um instrumento de medida da satisfação do paciente com a fisioterapia. Rev Bras Fisioter. 2007;11(5):369-76.

Received: 29/06/2008 - Revised: 07/11/2008 - Accepted: 26/01/2009

Graduate Program in Health Sciences, Universidade Federal do Rio Grande do Norte (UFRN), Natal (RN), Brazil

Department of Physical Therapy, UFRN

${ }^{3}$ Head of the Masters Program in Physical Therapy, UFRN

Correspondence to: Talita Pascalle Macedo Diógenes, Rua Acari, 28, Bairro Lagoa Nova, CEP 59063-280, Natal (RN), Brazil, e-mail: tpascalle@yahoo.com.br 


\section{Introduction $: \because 8$}

The redefining of patients as health service consumers has led to the adoption of strategies to improve health care based on an assessment of patient satisfaction ${ }^{1}$. Observing and knowing the behavior and opinion of patients is fundamental to understanding and improving both the care provided and the clinical environment ${ }^{2,3}$. Patient satisfaction surveys conducted as part of care follow-up are particularly important in providing therapists with feedback from patients about their physical therapy experiences ${ }^{4}$. Patient satisfaction is related to one of the elements of health status, and it is a measure of care quality, technical and interpersonal competence, immediate and positive non-verbal procedures, social conversation, courtesy, consideration, clear communication and information, respect, frequency of contact, prolonged consultation, availability of the care and waiting time ${ }^{5,6}$. A number of studies have focused on patient satisfaction as an indicator of health care quality, as a measure of the perception of the health services provided and as a result and continuity variable $e^{7,8}$.

The methodological procedures reported in the literature for approaching patient satisfaction defend the use of rigorously validated and standardized instruments, which have been steadily refined since the 1990s in the area of physical therapy, producing valid and reliable measures ${ }^{6,9-11}$. The results of one of the studies showed a possible influence of sociodemographic and psychosocial factors as well as interpersonal relations on patient satisfaction with physical therapy treatment ${ }^{12}$. Of all the sociodemographic variables, the individual's age appears to have the highest correlation with satisfaction ${ }^{13,14}$. However, little attention has been paid to the satisfaction of patient subgroups, including older adults, and it is wrong to assume that all patients have the same needs and expectations.

The repercussions of aging along with its associated infirmities on public health care systems are significant. Older adults are the largest consumers of these services worldwide ${ }^{15}$, and the effectiveness of geriatric care is often called into question $^{16}$. In Brazil, the rapid growth of the older adult population has had a great impact on its health care system, resulting in higher costs and greater use of the services. The inefficiency of traditional geriatric care models makes a change in the health care paradigm of this population indispensable. Improvements can be achieved by developing new health care models that identify, assess and treat older adults with different morbid and functional profiles.

Older adult patient satisfaction with the communication used at the first medical visit was analyzed ${ }^{17}$, and it was concluded that older adult patients prefer consultations where the doctors provide support and show empathy, and where they give patients the opportunity to voice their concerns. A study carried out by Juanola et al. ${ }^{15}$ investigated the degree of satisfaction of an older adult population with primary health services and found that women in the 60-69-year age group used these services more, mainly for medical consultations, outpatient care and diagnostic tools, but not for rehabilitation services. The level of overall geriatric satisfaction with these services was between $57.14 \%$ and $100 \%$.

There is a lack of scientific evidence about satisfaction in the rehabilitation area, an important fact, given the large older adult population that is increasingly in need of this care. The small production is restricted to the quantitative assessment of general services, and it is scarce with respect to resolution and patient satisfaction ${ }^{8}$. Therefore, the purpose of this study was: (1) to identify the levels of older adult patient satisfaction with physical therapy care using indicators of satisfaction, (2) to identify the emerging aspects that best correlate perceived satisfaction with the physical therapy care received, and (3) to assess the internal consistency of the assessment instrument (satisfaction assessment) when applied to an older adult population.

\section{Methods $\because \cdots$}

This study was approved by the Research Ethics Committee of Universidade Federal do Rio Grande do Norte (protocol 067/06). Prior written consent was obtained from all respondents. The confidentiality and anonymity of the responses was also guaranteed.

\section{Subjects}

The sample consisted of 242 older adult patients who received outpatient physical therapy treatment at 29 private clinics in Natal, Brazil. The inclusion criteria were the following: aged 60 years or older; having undergone between 5 and 60 physical therapy sessions at the clinic where the data were collected; and good cognitive function, assessed by Folstein's Mini-Mental State Examination - MMSE (cutoff points: illiterate - 13; low educational level [1 to 4 years] - 13; medium educational level [4 to 8 years] - 18; high educational level [more than 8 years] -26$)^{18}$. The selected subjects had scores equal to or greater than those previously described; this allowed them to understand and complete the questionnaire. A total of 221 volunteer patients who met the inclusion criteria were selected to take part in the study. The 21 patients excluded did not attain the MMSE cutoff for preserved cognitive function. 


\section{Instrument}

We used a self-completion instrument, developed for the Brazilian population, that assessed patient satisfaction with physical therapy. Psychometric properties were tested and demonstrated through reliability (Cronbach's alpha coefficient $=0.94$ ) and content analysis, as well as simultaneous and construct validity $^{6}$. The first part of the instrument is composed of descriptive questions about sociodemographic characteristics and the seeking of care. The satisfaction scale is composed of 23 items about aspects of the different patient satisfaction levels. These were scored using a 5-point interval scale that ranged from "very bad" to "excellent" on the first 21 items. The last two items ask about the patients' intentions with respect to returning to the facility, on a scale ranging from "never" to "certainly". There was also a section for patient comments.

\section{Pilot study}

The methodology proposed for data collection was pretested in 40 patients from 4 randomly selected clinics. Analysis showed that the measures obtained with the instrument were highly reliable (Cronbach's alpha coefficient $=0.957$ ). They were also compliant with the norms established for data collection.

\section{Data collection}

The data were collected between February and April 2007 in the waiting rooms of the participating clinics. The older adult patients who came to the clinic for treatment during the aforementioned period met the inclusion criteria. They agreed to take part in the study by signing a consent form.

\section{Data analysis}

The data were analyzed using SPSS 15.0 software. Descriptive and analytical statistics, reliability estimates and the degree of internal consistency of the measures were calculated using Cronbach's alpha coefficient. Descriptive statistics were measured using absolute and relative frequency distribution for the categorical variables and means with standard deviation (SD) for the continuous variables. The data underwent factorial analysis to identify the factorial structure of the indicators of satisfaction level. The Kaiser-Meyer-Olkin (KMO) measure of sampling adequacy was performed before factorial analysis to determine whether the data fit the factorial model ${ }^{6}$, while Bartlett's test of sphericity (BTS) tested the multivariate normality of the set of distributions ${ }^{19}$. The principal component analysis extraction method and oblique rotation were used because they are indicated for extracting theoretical concepts ${ }^{6}$.

\section{Results $\because \because$}

Table 1 shows the sociodemographic characteristics related to the care received by the 221 participants. The most prevalent physical therapy specialties were rheumatology, orthopedics/traumatology and neurology (48.0\%, 37.1\% and 5.9\%, respectively). Most of the patients reported being aware of their clinical diagnosis (77.4\%).

Table 1. Sociodemographic characteristics and those related to the health care of 221 older adult patients.

\begin{tabular}{|c|c|}
\hline \multicolumn{2}{|l|}{ Variables } \\
\hline Age, mean in years \pm S.D. & $70.9 \pm 7.574$ \\
\hline \multicolumn{2}{|l|}{ Sex, N (\%) } \\
\hline Male & $52(23.5)$ \\
\hline Female & $169(76.5)$ \\
\hline \multicolumn{2}{|l|}{ Marital state, N (\%) } \\
\hline Married & $110(49.8)$ \\
\hline Others & $111(50.2)$ \\
\hline \multicolumn{2}{|l|}{ Resides with, N (\%) } \\
\hline Family & $149(67.4)$ \\
\hline Spouse & $55(24.9)$ \\
\hline Alone & $9(4.1)$ \\
\hline Others & $8(3.6)$ \\
\hline \multicolumn{2}{|l|}{ Educational level, N (\%) } \\
\hline Illiterate & $7(3.2)$ \\
\hline Primary (incomplete) & $59(26.7)$ \\
\hline Primary & $37(16.7)$ \\
\hline Secondary (incomplete) & $20(9.0)$ \\
\hline Secondary & $56(25.3)$ \\
\hline Tertiary & $42(19.0)$ \\
\hline \multicolumn{2}{|l|}{ Family income, N (\%) } \\
\hline 1 to 3 times the minimum wage* & $60(27.1)$ \\
\hline 4 to 6 times the minimum wage* & 59 (26.7) \\
\hline 7 to 10 times the minimum wage* & $58(26.2)$ \\
\hline More than 10 times the minimum wage & $44(19.9)$ \\
\hline \multicolumn{2}{|l|}{ Clinic recommended by, $\mathrm{N}(\%)$} \\
\hline Doctor & $94(42.5)$ \\
\hline Friend & $44(19.9)$ \\
\hline Telephone directory & $2(0.9)$ \\
\hline Health insurance directory & $25(11.3)$ \\
\hline Previous patient & $22(10.0)$ \\
\hline Others & $34(15.4)$ \\
\hline \multicolumn{2}{|c|}{ First experience with the physical therapist, $\mathrm{N}(\%)$} \\
\hline Yes & $56(25.3)$ \\
\hline No & $165(74.7)$ \\
\hline \multicolumn{2}{|l|}{ First experience with the clinic, $\mathrm{N}(\%)$} \\
\hline Yes & $132(59.7)$ \\
\hline No & $89(40.3)$ \\
\hline Number of sessions, mean \pm S.D. & $18 \pm 15.110$ \\
\hline \multicolumn{2}{|l|}{ Physical therapists per patient, N (\%) } \\
\hline 1 & $134(60.5)$ \\
\hline 2 or more & $87(39.5)$ \\
\hline \multicolumn{2}{|l|}{ Sex of the physical therapist, N (\%) } \\
\hline Male & $18(8.1)$ \\
\hline Female & $176(79.5)$ \\
\hline Male/Female & $27(12.2)$ \\
\hline
\end{tabular}


The aspects that generate patient satisfaction presented in Table 2 show that the items related to the therapist-patient relationship were the most relevant, given the high complete satisfaction scores, especially with respect to the courtesy of the physical therapist. The complete satisfaction ("excellent" and "very good" scores) of $76.9 \%$ reported in item 21 shows that, in general, the population studied was satisfied with the physical therapy care received. The reliability of the means obtained with the study instrument, using Cronbach's alpha coefficient and intended for the geriatric population, found an $\alpha$ of 0.943 .

The study of sampling adequacy $(\mathrm{KMO}=0.924)$ indicated the applicability of the factorial model because the representative value shows that the set of data is strongly recommended for factorial analysis. BTS demonstrated a significant value (0.0001), suggesting that the data have near-normal multi-variety and are also acceptable for factorial analysis ${ }^{19}$. Table 3 shows the retained items in each extracted component after oblique rotation. To determine the most important factor for the quality of physical therapy care provided, given the dimensions obtained between the different patient satisfaction indicators, we used principal component analysis with four retained factors having autovalue greater than one as the extraction method (Table 4).

\section{Discussion $\because \because$.}

The results obtained in the study indicate that the instrument used is reliable for measuring the quality of the outpatient care provided to older adult patients. The reliability calculated by Cronbach's alpha coefficient $(\alpha=0.943)$ exceeded the values proposed as a criterion for exploratory studies ${ }^{20}$. It is suggested that an alpha value of 0.7 is acceptable ${ }^{19}$. The correlation of subscale 1 items, which encompass aspects related to physical therapist-patient interaction (Table 4, items of component 1), represented the highest level of satisfaction with care received by the older adult patients. This result corroborates findings from other studies, which show this domain as the main component associated to patient satisfaction with physical therapy ${ }^{6,9,10}$.

The questions related to convenience, such as availability of parking and location of the clinic, had the lowest internal consistencies and lowest autovalue on subscale 4 (convenience). This finding is contradictory, given that researchers from the USA $^{21}$ reported that patient satisfaction is strongly influenced by factors such as location and cost, whereas researchers from the $\mathrm{UK}^{21}$ found that accessibility, waiting time and attitude of the staff are critical components to patient satisfaction. These findings are from different health care systems, which could

Table 2. Descriptive statistics of the items related to aspects that generate satisfaction in older adult patients.

\begin{tabular}{|c|c|c|c|c|c|}
\hline \multirow{2}{*}{ Instrument items } & \multicolumn{2}{|c|}{$\begin{array}{l}\text { Complete } \\
\text { satisfaction }\end{array}$} & \multicolumn{2}{|c|}{$\begin{array}{l}\text { Incomplete } \\
\text { satisfaction }\end{array}$} & \multirow{2}{*}{$\begin{array}{c}\text { Tota } \\
\%\end{array}$} \\
\hline & $\mathrm{N}$ & $\%$ & $\mathrm{~N}$ & $\%$ & \\
\hline 1) Clear explanations given by the physical therapist about your treatment at the first consultation & 133 & 60.2 & 88 & 39.8 & 100 \\
\hline 2) A sense of security transmitted by the physical therapist during treatment & 147 & 66.5 & 74 & 33.5 & 100 \\
\hline 3) Doubt resolution by the physical therapist & 143 & 64.7 & 78 & 35.3 & 100 \\
\hline 4) Courtesy displayed by the physical therapist & 189 & 85.5 & 32 & 14.5 & 100 \\
\hline 5) The respect with which you are treated by the physical therapist & 186 & 84.2 & 35 & 15.8 & 100 \\
\hline 6) Privacy respected during your physical therapy session & 164 & 74.2 & 57 & 25.8 & 100 \\
\hline 7) Opportunity given by the physical therapist to express yourself during the assessment of your problem & 150 & 67.9 & 71 & 32.1 & 100 \\
\hline 8) Thorough assessment of your problem & 132 & 59.7 & 89 & 40.3 & 100 \\
\hline 9) Courtesy of the other team members & 154 & 69.7 & 67 & 30.3 & 100 \\
\hline 10) Courtesy and availability of the receptionist & 164 & 74.2 & 57 & 25.8 & 100 \\
\hline 11) Ease in scheduling your first consultation after referral & 151 & 68.3 & 70 & 31.7 & 100 \\
\hline 12) Ease in scheduling sessions after the first consultation & 160 & 72.4 & 61 & 27.6 & 100 \\
\hline 13) Availability of convenient times to undergo your treatment & 155 & 70.1 & 66 & 29.9 & 100 \\
\hline 14) Time spent in the waiting room beyond the scheduled hour & 138 & 62.4 & 83 & 37.6 & 100 \\
\hline 15) Convenience of the clinic's location & 127 & 57.5 & 94 & 42.5 & 100 \\
\hline 16) Availability of parking & 88 & 39.9 & 133 & 60.1 & 100 \\
\hline 17) Comfort in the waiting room & 112 & 50.6 & 109 & 49.4 & 100 \\
\hline 18) Comfort of the environment where the physical therapy was performed & 122 & 55.2 & 99 & 44.8 & 100 \\
\hline 19) General hygiene conditions of the clinic & 139 & 62.9 & 82 & 37.1 & 100 \\
\hline 20) Ease of movement within the facilities of the clinic & 131 & 59.3 & 90 & 40.7 & 100 \\
\hline 21) General satisfaction with your experience with the physical therapist & 170 & 76.9 & 51 & 23.1 & 100 \\
\hline 22) You would return to this clinic if future treatment were necessary & 211 & 95.4 & 10 & 4.6 & 100 \\
\hline 23) You would recommend this clinic to family members and friends & 216 & 97.7 & 5 & 2.3 & 100 \\
\hline
\end{tabular}


Table 3. Rotation components matrix of the instrument measuring patient satisfaction with physical therapy applied to older adult patients.

\begin{tabular}{|c|c|c|c|c|}
\hline \multirow{2}{*}{ Item } & \multicolumn{4}{|c|}{ Component } \\
\hline & 1 & 2 & 3 & 4 \\
\hline Doubt resolution by the physical therapist & 0.765 & & & \\
\hline A sense of security transmitted by the physical therapist during treatment & 0.750 & & & \\
\hline Courtesy displayed by the physical therapist & 0.730 & & & \\
\hline The respect with which you were treated by the physical therapist & 0.723 & & & \\
\hline Clear explanations about your treatment given by the physical therapist at the first session & 0.705 & & & \\
\hline Opportunity given by the physical therapist to express yourself during the assessment of your problem & 0.673 & & & \\
\hline Thorough assessment of your problem & 0.568 & & & \\
\hline Ease in scheduling sessions after the first consultation & & 0.799 & & \\
\hline Ease in scheduling your first consultation after referral & & 0.783 & & \\
\hline Availability of convenient times to undergo your treatment & & 0.731 & & \\
\hline Privacy respected during your physical therapy session & & 0.597 & & \\
\hline Courtesy and availability of the receptionist & & 0.571 & & \\
\hline Comfort of the environment where the physical therapy was performed & & 0.533 & & \\
\hline Time spent in the waiting room beyond the scheduled hour & & 0.507 & & \\
\hline Courtesy of the other team members & & 0.506 & & \\
\hline You would return to this clinic if future treatment were necessary & & & 0.829 & \\
\hline You would recommend this clinic to family members and friends & & & 0.813 & \\
\hline General hygiene conditions of the clinic & & & 0.540 & \\
\hline Ease of movement within the facilities of the clinic & & & 0.480 & \\
\hline General satisfaction with your experience with the physical therapist & & & 0.468 & \\
\hline Convenience of the clinic's location & & & & 0.792 \\
\hline Availability of parking & & & & 0.780 \\
\hline Comfort in the waiting room & & & & 0.521 \\
\hline
\end{tabular}

Table 4. Total variance explained and the reliability coefficient for each component removed from the instrument measuring patient satisfaction with physical therapy applied to older adult patients.

\begin{tabular}{lcccc}
\hline Component $^{*}$ & Eigevalue & Percentage of total variance explained & Accumulated percentage of total variance explained & Alpha $(\alpha)$ \\
\hline 1 & 10.491 & 45.614 & 45.614 & 0.901 \\
\hline 2 & 1.626 & 7.072 & 52.686 & 0.888 \\
\hline 3 & 1.299 & 5.650 & 58.336 & 0.835 \\
\hline 4 & 1.165 & 5.067 & 63.402 & 0.711 \\
\hline
\end{tabular}

${ }^{*}$ Component 1: Patient-therapist interaction (7 items); Component 2: Access and courtesy of the receptionist and of the support personnel (8 items); Component 3: Physical environment and overall satisfaction (5 items); Component 4: Convenience (3 items).

explain this apparent 'contradiction'. However, these items were explained in most studies that do not have the same retention power in measuring the satisfaction construct, if compared to the remaining items and/or domains, mainly the therapist-patient relationship ${ }^{6,9,10,22,23}$. It is further corroborated when we report on an older adult population whose expectations about care are based on their relationship with the physical therapist and the courtesy shown at treatment sessions. The factorial structure resulting from the analysis of this study was similar to that performed in an earlier investigation in the same sociocultural context, albeit in a general population; that is, not stratified by age ${ }^{6}$. The factorial structure obtained in our study might better explain the satisfaction level of older adult patients, if we consider the four subscales formed here, all of which had an autovalue greater than one and $\alpha>0.7$.

The dimension most widely reported, and most strongly associated with the assessment of patient satisfaction with respect to the quality of the service provided, is reflected in the attentive communication of those who care for the patients. These assumptions contribute to patient satisfaction with treatment and improved prognosis, since the latter, along with the evolution of physical therapy treatment, depends directly on the interpersonal relationship between the patient and the physical therapist. Thus, we face the dilemma that exists between classical therapies, state-of-the-art equipment and a more attentive care ${ }^{24}$. Fitzpatrick ${ }^{25}$ proposed "the importance of emotional needs" satisfaction model, emphasizing emotional experience as an important health problem, caused in part by uncertainty and anxiety, but also by the inability of patients to judge the technical competence of professionals. Consequently, patients base their satisfaction on the attentive behavior and communication skills of the professional.

With the perspective of a more humanistic therapy, we can reflect on a wider meaning of care; that is, an exchange 
between the therapist and the patient that associates emotion to the professional's technique. The ability of individuals to deal with relationships more effectively, and to satisfy their needs and those of others, is called interpersonal competence ${ }^{24}$. An earlier study indicated that patients use the quality of interpersonal skills as a reference for assessing the performance of a professional ${ }^{6}$.

Friedman ${ }^{26}$ reported that the emotions involved in the disease process make the patients more sensitive, and that they observe carefully, not only the verbal communication skills of professionals, but also non-verbal communication. Tone of voice, facial expression, smiles, touch and physical distance are the main signs of non-verbal communication that transmit the idea of the existence of an interpersonal interaction between the parties involved in the process ${ }^{27}$. Buller and Buller ${ }^{28}$ found that professionals who behave in a dominating way and who control the style of communication produce less satisfaction in their patients. Other studies also support these findings by showing that satisfaction with treatment is more strongly related to the perceptions of attentive behavior exhibited by the caregiver than to factors related to technical skills and administrative aspects ${ }^{28}$.

Although the degree of older adult patient satisfaction showed high overall satisfaction scores (very good, excellent), it may have been underestimated, given that the score "good" was included in the dichotomization of the scale as "not completely satisfied", ${ }^{8,1213}$. Thus, several items of this new recategorization did not show negative perceptions (bad, very bad); questions 2,3,4,5,7,9,18 and 23 include only "good" in the not completely satisfied category, while questions 2 to 7 are related to the therapist-patient interaction. Therefore, to achieve patient satisfaction in areas other than the quality of the professional and of the educational and operational infrastructure of the clinic, institutions must implement a policy, aimed at the social transformation of the professional, that encourages medical ethics, considers the real commitment of the professional in the health area and seeks to establish responsibility for the social well-being of the patient ${ }^{29,30}$. It must also be pointed out that the classical models of promotion, prevention, care and rehabilitation cannot be mechanically applied to groups of older adult individuals without important and significant adaptations. This requires the inclusion of physical therapists specialized in geriatrics to better meet the needs of these patients.

The present study shows the multidimensionality of the patient satisfaction construct, with an emphasis on interpersonal interaction, which is lacking in the current literature, especially communication aspects such as the respect and courtesy displayed by the physical therapist. Older adult individuals with loss of functional capacity have permanent health care needs. They are the group that most uses health services given the high prevalence of chronic diseases, especially those related to the rehabilitation process. Physical therapists, as part of this process, must provide support to these patients, not only through their technical skills, but also by emphasizing an attentive and positive interpersonal relationship, which are the most mentioned aspects of older patient satisfaction with health care.

\section{References}

1. Passos ICF. Mesa redonda: Avaliação de políticas e serviços de saúde mental: Olhares diferentes. XI Encontro Nacional da ABRAPSO; 2001.

2. Rosa MC, Lage MCA, Pérez MC, Ibarra AM. Satisfacción de los pacientes com la atención médica. Rev Cuba Med Gen Integr. 1999;15(5):541-7.

3. Kotaka F, Pacheco MLR, Higaki Y. Avaliação pelos usuários dos hospitais participantes do programa de qualidade hospitalar no Estado de São Paulo, Brasil. Rev Saúde Pública. 1997;31(2):171-7.

4. Hills R, Kitchen S. Satisfaction with outpatient physiotherapy: a survey comparing the views of patients with acute and chronic musculoskeletal conditions. Physiother Theory Pract. 2007;23(1):21-36.

5. Westaway MS, Rheeder P, van Zyl DG, Seager JR. Interpersonal and organizational dimensions of patient satisfaction: the moderating effects of health status. Int J Qual Health Care. 2003;15(4):337-44.

6. Mendonça KMPP, Guerra RO. Desenvolvimento e validação de um instrumento de medida da satisfação do paciente com a fisioterapia. Rev Bras Fisioter. 2007;11(5):369-76.
7. Halal IS, Sparrenberge F, Bertoni AM, Ciacomet C, Seibel CE, Lahude FM, et al. Avaliação da qualidade de assistência primária à saúde em localidade urbana da região sul do Brasil. Rev Saúde Pública. 1994;28(2): 131-6.

8. Hsieh MO, Kagle JD. Understanding patient satisfaction and dissatisfaction with health care. Health Soc Work. 1991;16(4):281-90.

9. Goldstein MS, Elliot SD, Guccione AA. The development of an instrument to measure satisfaction with physical therapy. Phys Ther. 2000;80(9): 853-63.

10. Beattie PF, Pinto MB, Nelson MK, Nelson R. Patient satisfaction with outpatient physical therapy: instrument validation. Phys Ther. 2002;82(6):557-65.

11. Roush SE, Sonstroem RJ. Development of the physical therapy outpatient satisfaction survey (PTOPS). Phys Ther. 1999;79(2):159-70.

12. Diógenes TPM, Lima TMFS, Mendonça KMPP. Fisioterapia: Você está satisfeito? Fiep Bulletin. 2005;7:41-4. 
13. Mendonça KMPP, Lima TMFS, Diógenes TPM. Influência das características sócio-demográficas na satisfação do paciente com 0 tratamento fisioterapêutico. Fisioter Mov. 2006;19(3):83-9.

14. Calnan M, Almond S, Smith N. Ageing and public satisfaction with the health service: an analysis of recent trends. Soc Sci Med. 2003;57(4): $757-62$.

15. Juanola MG, Carvajal AP, Rodriguez MM, Llanes MR. Satisfacción de los adultos mayores com los servicios de salud em el nível primário. Rev Cuba Méd Gen Integr [periódico na Internet]. 2004 [acesso em 07/06/2005]; 20(3):[aproximadamente 4 p.]. Disponível em: http://bvs.sld.cu/revistas/ mgi/vol20_3_04/mgi07304.htm

16. Coelho Filho JM. Modelos de serviços hospitalares para casos agudos em idosos. Rev Saúde Pública. 2000;34(6):666-71.

17. Grenee MG, Adelman RD, Friedman E, Charon R. Older patient satisfaction with communication during an initial medical encounter. Soc Sci Méd. 1994;38(9):1279-88.

18. Bertolucci PHF, Brucki SMD, Campacci SR, Juliano Y. O mini-exame do estado mental em uma população geral: impacto da escolaridade. Arq Neuropsiquiatr. 1994;52:1-7.

19. Mostafa MM. An empirical study of patient's expectations and satisfaction in Egyptian hospitals. Int J Health Care Qual Assur Inc Leadersh Health Serv. 2005;18(6-7):516-32.

20. Malhotra NK. Pesquisa de marketing: uma orientação aplicada. $3^{\mathrm{a}}$ ed. Porto Alegre - (RS): Bookman; 2001.

21. Mclver S. Obtaining the views of outpatients. London: King's Fund; 1991.
22. Pascoe GC, Attkisson CC, Roberts RE. Comparison of indirect and direct approaches to measuring patient satisfaction. Eval Program Plann. 1983;6(3-4):359-71.

23. Etter JF, Perneger TV. Validating a satisfaction questionnaire using multiple approaches: a case study. Soc Sci Méd. 1997;45(6):879-85.

24. Sacheto RM, Sandoval JMH. A comunicação como estratégia complementar no cuidado fisioterapêutico geriátrico. UNESCO [periódico na Internet]. 2003 Out. [acesso em 5 Maio 2005]; [aproximadamente 15p]. Disponível em: http://encipecom.metodista.br/mediawiki/index. php/A_comunica\%C3\%A7\%C3\%A30_como_estrat\%C3\%A9gia_ complementar_no_cuidado_fisioterap\%C3\%AAutico_geri\%C3\%A1trico.

25. Fitzpatrick R. Satisfaction with health care. In: Fitzpatrick F, Hinton J, Newman S, Scambler G, Thompson J (editors). The experience of IIIness. London: Tovistock; 1984. p. 154-75.

26. Friedman HS. Non-verbal communication between patients and medical practioners. J Soc Issues. 1979;35:82-99.

27. DiMatteo MR, Taranta A, Friedman HS, Prince LM. Predicting patient satisfaction from physician's nonverbal communication skills. Med Care. 1980; 18(4):376-87.

28. Buller MK, Buller DB. Physicians' communication style and patient satisfaction. J Health Soc Behav. 1987;28(4):375-84.

29. Rodrigues RB. Como conquistar a preferência dos pacientes. Saúde Business Web. 2004;1-3.

30. Jaipaul CK, Rosenthal GE. Are older patients more satisfied with hospital care than younger patients? J Gen Intern Med. 2003;18(1):23-30. 